\title{
Optimization of Cotton Mixing Cost: A Fuzzy Linear Programming APPROACH
}

\author{
Subhasis Das ${ }^{1}$; Anindya Ghosh \\ Government College of Engineering \& Textile Technology, \\ Department of Textile Technology, Berhampore, India \\ e-mail: ${ }^{1}$ subhasis.tex@gmail.com
}

\begin{abstract}
This paper deals with the minimization of the cost for three types of cotton mixings suitable for the production of fine, medium and coarse yarns without impinging the required quality using the fuzzy linear programming, which is the amalgamation of fuzzy logic and classical linear programming. The findings of this work point out that the fuzzy linear programming attains the best solution of cotton mix in comparison with its classical version as well as the existing method followed in cotton spinning industry.
\end{abstract}

\section{Introduction}

The concept of fuzzy linear programming was first proposed by Bellman and Zadeh [1]. Thereafter, Zimmermann [2], Verdegay [3, 4], Chanas [5], Werners [6], Tan [7] etc. made significant contributions in the development of fuzzy linear programming. Elamvazuthi et al. [8] used fuzzy linear programming in production planning in textile industry.

Judicious mixing of different types of cotton fibres is an optimization problem for obtaining raw material with required quality at a minimum cost in the cotton spinning industries. In this work an attempt has been made to solve the cotton mixing problem using fuzzy linear programming approach. The case studies have been made on three types of cotton mixings suitable for the production of fine, medium and coarse yarns. The data for this problem are taken from the cotton spinning industry. In keeping with the traditional industrial practice, two varieties of cottons are considered for each type of mixing. A comparative study of the relative performances of fuzzy linear programming and its classical version is presented here. It also attempts to establish its effectiveness over the usual practice as followed by the cotton spinning industry.

\section{$1 \quad$ Optimization of Cotton Mixing Cost}

Cotton fibre mixings suitable for the production of fine, medium and coarse yarns are considered in this study, and the data were collected from the cotton spinning industry. For each type of mixing two varieties of cottons are used. The objective of this study is to determine the proportion of cottons for each type of mixing to achieve the best quality yarns at the lowest raw material cost. Judging from theory and a practical standpoint, four fibre properties, such as fibre bundle strength, upper half mean length (UHML), fibre fineness and short fibre content (SFC) are considered since they exert a strong influence on the yarn quality. Table 1 depicts the fibre properties and costs for different types of cottons. 
Tab. 1: Fibre properties and cost for different type of cotton mixing

\begin{tabular}{|l|l|c|c|c|c|c|}
\hline $\begin{array}{c}\text { Mixing } \\
\text { type }\end{array}$ & $\begin{array}{c}\text { Cottons } \\
\text { used }\end{array}$ & $\begin{array}{c}\text { Bundle } \\
\text { strength } \\
(\mathbf{c N} / \mathbf{t e x})\end{array}$ & $\mathbf{U H M L}$ & Fineness & $\begin{array}{c}\text { Short fibre } \\
\text { content } \\
(\mathbf{m})\end{array}$ & $\begin{array}{c}\text { Cost / 100 Kg } \\
\text { cottons } \\
\text { (US) }\end{array}$ \\
\hline \multirow{2}{*}{ Fine } & ULTIMA & 34.5 & 31.80 & 3.9 & 20.90 & 394.40 \\
\cline { 2 - 7 } & PIMA & 38.8 & 34.30 & 4.2 & 12.50 & 367.00 \\
\hline \multirow{2}{*}{ Medium } & DCH -32 & 39.1 & 35.12 & 4.2 & 16.10 & 291.40 \\
\cline { 2 - 7 } & MCU-5 & 31.5 & 31.10 & 4.3 & 21.50 & 269.53 \\
\hline \multirow{2}{*}{ Coarse } & J-34 & 32.1 & 28.73 & 4.8 & 19.70 & 268.80 \\
\cline { 2 - 7 } & S-6 & 31.3 & 28.17 & 4.4 & 20.16 & 281.64 \\
\hline
\end{tabular}

Source: Own

\subsection{Fuzzy Linear Programming Approach}

As the bundle strength and UHML are benefit criteria where higher values are desirable, and fineness and SFC are cost criteria where lower values are better, the problem for each type of cotton mixing can be formulated as the following fuzzy linear programming problem:

Minimize

$$
c_{1} x_{1}+c_{2} x_{2}
$$

(mixing cost)

Subject to,

$$
\begin{gathered}
a_{11} x_{1}+a_{12} x_{2} \geq E_{1} \\
a_{21} x_{1}+a_{22} x_{2} \geq E_{2} \\
\frac{x_{1}}{a_{31}}+\frac{x_{2}}{a_{32}} \geq \frac{1}{E_{3}} \\
a_{41} x_{1}+a_{42} x_{2} \leq E_{4} \\
x_{1}+x_{2}=1 \\
x_{1}, x_{2} \geq 0
\end{gathered}
$$

where $x_{1}$ and $x_{2}$ are the proportions of two varieties of cottons, $c_{1}$ and $c_{2}$ are their corresponding costs, $E_{1}, E_{2}, E_{3}$ and $E_{4}$ represent the monotonically decreasing membership function for the constrains such as fibre bundle strength, UHML, fineness and SFC, respectively.

The objective functions and constraint equations for fine, medium and coarse cotton mixings are formulated in Table 2. The membership functions for the various constraints of a particular mixing are determined by translating our perception and experience from the available fibre data. The obvious equality constraint in the product mix problem is the sum of $x_{1}$ and $x_{2}$ equals to one. MATLAB 7.11 coding has been used to solve the problems. 
Tab. 2: Objective functions, fuzzy numbers and constraints of fuzzy linear programming for different cotton

\begin{tabular}{|c|c|c|c|}
\hline Mixing type & Fine & Medium & Coarse \\
\hline $\begin{array}{l}\text { Objective } \\
\text { Function }\end{array}$ & $394.4 x_{1}+367.0 x_{2}$ & $291.4 x_{1}+269.53 x_{2}$ & $268.8 x_{1}+281.64 x_{2}$ \\
\hline E1 & $\begin{array}{c}1 \text { when } x \leq 28.5 \\
\frac{38.5-x}{38.5-29.5} \text { when } 28.5<x \leq 38.5 \\
0 \text { when } 38.5<x\end{array}$ & $\begin{array}{l}1 \text { when } x \leq 27.5 \\
\frac{38.0-x}{38.0-27.5} \text { when } 27.5<x \leq 38.0 \\
0 \text { when } 38.0<x\end{array}$ & $\begin{array}{c}1 \text { when } x \leq 28.5 \\
\frac{32.0-x}{32.0-28.5} \text { when } 28.5<x \leq 32.0 \\
0 \text { when } 32.0<x\end{array}$ \\
\hline E2 & $\begin{array}{c}1 \text { when } x \leq 27.5 \\
\frac{35.2-x}{35.2-27.5} \text { when } 27.5<x \leq 35.2 \\
0 \text { when } 35.2<x\end{array}$ & $\begin{array}{c}1 \text { when } x \leq 27.5 \\
\frac{35.0-x}{35.0-27.5} \text { when } 27.5<x \leq 35.0 \\
0 \text { when } 35.0<x\end{array}$ & $\begin{array}{c}1 \text { when } x \leq 26.5 \\
\frac{29.0-x}{29.0-26.5} \text { when } 26.5<x \leq 29.0 \\
0 \text { when } 29.0<x\end{array}$ \\
\hline E3 & $\begin{array}{c}1 \text { when } \frac{1}{x} \leq \frac{1}{4.3} \\
\frac{\frac{1}{3.5}-\frac{1}{x}}{\frac{1}{3.5}-\frac{1}{4.3}} \text { when } \frac{1}{4.3}<\frac{1}{x} \leq \frac{1}{3.5} \\
0 \text { when } \frac{1}{3.5}<\frac{1}{x}\end{array}$ & $\begin{array}{c}1 \text { when } \frac{1}{x} \leq \frac{1}{4.8} \\
\frac{1}{\frac{1}{3.7}-\frac{1}{x}} \text { when } \frac{1}{4.8}<\frac{1}{x} \leq \frac{1}{3.7} \\
0 \text { when } \frac{1}{3.7}<\frac{1}{x}\end{array}$ & $\begin{array}{c}1 \text { when } \frac{1}{x} \leq \frac{1}{4.9} \\
\frac{\frac{1}{3.9}-\frac{1}{x}}{\frac{1}{3.9}-\frac{1}{4.9}} \text { when } \frac{1}{4.9}<\frac{1}{x} \leq \frac{1}{3.9} \\
\text { 0 when } \frac{1}{3.9}<\frac{1}{x}\end{array}$ \\
\hline E4 & $\begin{array}{c}1 \text { when } x \leq 10.0 \\
\frac{16.0-x}{16.0-10.0} \text { when } 10.0<x \leq 16.0 \\
0 \text { when } 16.0<x\end{array}$ & $\begin{array}{c}1 \text { when } x \leq 15.5 \\
\frac{20.5-x}{20.5-15.5} \text { when } 15.5<x \leq 20.5 \\
0 \text { when } 20.5<x\end{array}$ & $\begin{array}{c}1 \text { when } x \leq 18.0 \\
\frac{20.5-x}{20.5-18.0} \text { when } 18.0<x \leq 20.5 \\
0 \text { when } 20.5<x\end{array}$ \\
\hline $\begin{array}{l}\text { Equality } \\
\text { constraints }\end{array}$ & $x_{1}+x_{2}=1$ & $x_{1}+x_{2}=1$ & $x_{1}+x_{2}=1$ \\
\hline $\begin{array}{l}\text { Variable } \\
\text { boundary }\end{array}$ & $x_{1}, x_{2} \geq 0$ & $x_{1}, x_{2} \geq 0$ & $x_{1}, x_{2} \geq 0$ \\
\hline
\end{tabular}

Source: Own

\subsection{Linear Programming Approach}

The same objective functions are also solved using the linear programming problem which is formulated as:

minimize

$$
c_{1} x_{1}+c_{2} x_{2}
$$

subject to,

$$
\begin{gathered}
a_{11} x_{1}+a_{12} x_{2} \geq e_{1} \\
a_{21} x_{1}+a_{22} x_{2} \geq e_{2} \\
\frac{x_{1}}{a_{31}}+\frac{x_{2}}{a_{32}} \geq \frac{1}{e_{3}} \\
a_{41} x_{1}+a_{42} x_{2} \leq e_{4} \\
x_{1}+x_{2}=1 \\
x_{1}, x_{2} \geq 0
\end{gathered}
$$

Constraints of linear programming problem for different cotton mixings are tabulated in Table 3. 
Tab. 3: Constraints of linear programming problem for different cotton mixings

\begin{tabular}{|l|l|c|c|c|}
\hline \multicolumn{2}{|c|}{ Mixing type } & Fine & Medium & Coarse \\
\hline \multirow{4}{*}{$\begin{array}{l}\text { Inequality } \\
\text { constraints: }\end{array}$} & Strength & $34.5 x_{1}+38.8 x_{2} \geq 36.5$ & $39.1 x_{1}+31.5 x_{2} \geq 35.0$ & $32.1 x_{1}+31.3 x_{2} \geq 31.6$ \\
\cline { 2 - 5 } & UHML & $31.8 x_{1}+34.3 x_{2} \geq 33.1$ & $35.12 x_{1}+31.1 x_{2} \geq 33.1$ & $28.73 x_{1}+28.17 x_{2} \geq 28.1$ \\
\cline { 2 - 5 } & Fineness & $\frac{x_{1}}{3.9}+\frac{x_{2}}{4.2} \geq \frac{1}{4.1}$ & $\frac{x_{1}}{4.2}+\frac{x_{2}}{4.3} \geq \frac{1}{4.25}$ & $\frac{x_{1}}{4.8}+\frac{x_{2}}{4.4} \geq \frac{1}{4.6}$ \\
\cline { 2 - 5 } & SFC & $20.9 x_{1}+12.5 x_{2} \leq 17.0$ & $16.1 x_{1}+21.5 x_{2} \leq 18.5$ & $19.7 x_{1}+20.16 x_{2} \leq 20.5$ \\
\hline \multirow{2}{*}{ Equality constraints } & $x_{1}+x_{2}=1$ & $x_{1}+x_{2}=1$ & $x_{1}+x_{2}=1$ \\
\hline Variable boundary & $x_{1}, x_{2} \geq 0$ & $x_{1}, x_{2} \geq 0$ & $x_{1}, x_{2} \geq 0$ \\
\hline
\end{tabular}

Source: Own

The performance of fuzzy linear programming for optimizing cotton mixing cost has been compared with that of linear programming vis-à-vis the existing mill practice. Table 4 illustrates the optimum proportion of cotton mixing as well as the mixing cost as obtained by different approaches.

Tab. 4: Mixing cost as obtained by different method

\begin{tabular}{|c|c|c|c|c|c|c|c|}
\hline \multirow[b]{2}{*}{$\begin{array}{l}\text { Mixing } \\
\text { type }\end{array}$} & \multirow[b]{2}{*}{ Cottons used } & \multicolumn{2}{|c|}{ Industry practice } & \multicolumn{2}{|c|}{ Linear programming } & \multicolumn{2}{|c|}{$\begin{array}{l}\text { Fuzzy linear } \\
\text { programming }\end{array}$} \\
\hline & & \begin{tabular}{|c|} 
Mixing \\
proportion
\end{tabular} & $\begin{array}{c}\text { Mixing } \\
\text { cost } \\
(\$ / 100 k g) \\
\end{array}$ & $\begin{array}{c}\text { Mixing } \\
\text { proportion }\end{array}$ & $\begin{array}{c}\text { Mixing } \\
\text { cost } \\
(\$ / 100 k g) \\
\end{array}$ & $\begin{array}{c}\text { Mixing } \\
\text { proportion }\end{array}$ & $\begin{array}{c}\text { Mixing } \\
\text { cost } \\
(\$ / 100 k g) \\
\end{array}$ \\
\hline Fine & ULTIMA/PIMA & $50 / 50$ & 380.70 & $32 / 68$ & 375.76 & $27 / 73$ & 374.73 \\
\hline Medium & DCH-32/ MCU-5 & $60 / 40$ & 282.65 & $56 / 44$ & 281.68 & $37 / 63$ & 277.53 \\
\hline Coarse & $\mathrm{J}-34 / \mathrm{S}-6$ & $50 / 50$ & 275.22 & $52 / 48$ & 274.93 & $81 / 19$ & 271.29 \\
\hline
\end{tabular}

Source: Own

The obtained properties of three types of cotton mixings solved by both fuzzy linear programming and linear programming are given in Table 5. It is observed from Tables 4 and 5 that the fuzzy linear programming invariably provides the best solution of the mixing proportion by fulfilling the condition of all constraints to ensure the least mixing cost. As an example, it is evident from Table 4 that in the case of fine mixing, the mixing cost per $100 \mathrm{~kg}$ is reduced from $\$ 380.70$ to $\$ 375.76$ while the problem is solved by linear programming and the mixing cost is further curbed down to $\$ 374.73$ while it is solved by fuzzy linear programming. It thus follows that a mix of 32/68 of ULTIMA and PIMA cottons as obtained by linear programming produces a cheaper mixing than the $50 / 50$ mix as practiced by the mill for a fine mixing, further a mix of $27 / 73$ as obtained by the fuzzy linear programming yields a minimum mixing cost.

Tab. 5: Obtained properties of the cotton mixing

\begin{tabular}{|l|l|c|c|c|c|}
\hline & $\begin{array}{c}\text { Mixing } \\
\text { type }\end{array}$ & $\begin{array}{c}\text { Bundle } \\
\text { strength } \\
\text { (cN / tex })\end{array}$ & $\begin{array}{c}\text { Upper half } \\
\text { mean length } \\
\text { (mm) }\end{array}$ & $\begin{array}{c}\text { Fineness } \\
\text { (micronaire } \\
\text { value) }\end{array}$ & SFC \\
$\mathbf{( \% )}$
\end{tabular}

Source: Own 
A similar kind of observation is noted in the case of medium and coarse cotton mixings as shown in Table 4. The dominance of fuzzy linear programming for the cotton mixing problem may be attributable to its ability of handling the situation where there are no exact defined boundaries for the inequality constraints. For example, a spinner often uses the terms such as low and high to assess the fibre strength, length, fineness and SFC etc., however these terms do not constitute a well-defined boundary. All these fibre properties have approximate boundaries rather than exact boundaries. In addition, the membership functions for the various constraints could be developed by deciphering the experience of a spinner which renders a better utilization of the fibre properties needed for a particular mixing. Therefore, fuzzy linear programming satisfies both the goal and constraints with a maximum degree.

\section{Conclusion}

Fuzzy linear programming is used to optimize the raw material cost pertaining to three cotton mixings suitable for the production of fine, medium and coarse yarns. As per frequently followed industrial practice, two varieties of cottons are considered for each type of mixing. The solution obtained by fuzzy linear programming for the cotton mixing problem has been compared with that of linear programming as well as the existing system as practised by the cotton spinning industry. Fuzzy linear programming emerges as the most potent approach in this regard for all types of mixings followed by the linear programming. Fuzzy linear programming can enable to handle the imprecision that is present in the inequality constraints of fibre strength, length, fineness and SFC. A diminutive reduction in the raw material cost per $100 \mathrm{~kg}$ by retaining the fibre quality at a requisite level may lead to a considerable amount of economic gain to the cotton spinning industry. Therefore, the fuzzy linear programming approach of selection of the cotton mix has an enormous scope for industrial acceptance.

\section{Literature}

[1] BELlMAN, R. E.; ZADEH, L.A.: Decision Making in a Fuzzy Environment. Management Science. 1970, 17, 141-164.

[2] ZIMMERMANN, H.J.: Fuzzy Sets \& Systems. 1978, 1, 45-55.

[3] VERDEGAY, J. L.: Fuzzy mathematical programming. In: Gupta, M. M. and Sanchez, E. (eds.) Fuzzy Information and Decision Processes. Amsterdam, 1982.

[4] VERDEGAY, J. L.: Fuzzy Sets \& Systems. 1984, 1, 131-141.

[5] CHANAS, S.: Fuzzy sets \& Systems. 1983, 11, 243-251.

[6] WERNERS, B.: European Journal of Operations Research. 1987, 31, 342-349.

[7] TAN, R. R.: Environmental Modeling \& Software. 2005, 20, 1343-1346.

[8] ELAMVAZUTHI, I.; GANESAN, T.; VASANT, P.; WEBB, F. J.: International Journal of Computer Science and Information Security. 2009, 6, 238-243.

Subhasis Das; Anindya Ghosh 


\section{OPTIMALIZACE CENY BAVLNĚNÝCH SMĚSÍ: PŘÍSTUP FUZZY LINEÁRNÍHO PROGRAMOVÁNÍ}

Tento článek se zabývá minimalizací nákladů u tří typů bavlněných směsí vhodných pro výrobu jemné, střední a hrubé příze, aniž by byla ohrožena požadovaná kvalita, pomocí tzv. fuzzy lineárního programování, které je sloučením fuzzy logiky a klasického lineárního programování. Závěr této práce poukazuje na to, že fuzzy lineární programování dosahuje u bavlněných směsí lepšího výsledku ve srovnání s klasickou verzí, jakož i se stávajícími metodami používanými při průmyslovém předení bavlny.

\section{KOSTENOPTIMIERUNG FÜR BAUMWOLLMISCHUNGEN: ANSATZ DER FUZZY LINEARE PROGRAMMIERUNG}

Dieser Artikel befasst sich mit der Kostenminimierung bei drei Typen von Baumwollmischungen bei gleichbleibender Qualität, die zur Herstellung feiner, mittlerer und grober Garne geeignet sind. Dies geschieht mit Hilfe des so genannten Fuzzy Lineare Programmierung, welches in einem Zusammenschluss von Fuzzy-Logik und dem klassischen linearen Programmieren besteht. Die Ergebnisse dieser Arbeit zeigen, dass das Fuzzy Lineare Programmierung bei Baumwollmischungen im Vergleich mit der klassischen Version und mit den bestehenden, beim industriellen Verspinnen der Baumwolle angewandten Methoden bessere Ergebnisse aufweist.

\section{OPTYMALIZACJA CENY MIESZANEK BAWEŁNY: ZASTOSOWANIE ROZMYTEGO PROGRAMOWANIA LINIOWEGO}

Niniejszy artykuł poświęcony jest zagadnieniu minimalizacji kosztów w przypadku trzech rodzajów mieszanek bawełny nadających się do produkcji cienkiej, średniej i grubej przędzy przy zachowaniu wymaganej jakości, $\mathrm{z}$ zastosowaniem metody tzw. rozmytego programowania liniowego (fuzzy linear programming), która jest połączeniem logiki rozmytej i klasycznego programowania liniowego. W zakończniu niniejszego opracowania wskazano, że rozmyte programowanie liniowe daje w przypadku mieszanek bawełny lepsze efekty w porównaniu $\mathrm{z}$ wersją klasyczną, jak i istniejącymi metodami stosowanymi w przemysłowym przędzeniu bawełny. 